\title{
INTERPRETASI KISAH NABI MUSA PERSPEKTIF NARATOLOGI AL-QUR'ÂN
}

\author{
M. Faisol
}

Universitas Islam Negeri Maulana Malik Ibrahim Malang, Indonesia E-mail:mfaisolfatawi@gmail.com

\begin{abstract}
The narrative structure of the story of Musa in the Qur'ân is constructed by a plausible and rapid plot. Furthermore, this story has a constant narrative structure that is narrator-creator-sender (Allah) as the one who sends the message, the first receiver (the Prophet Muhammad) as the messenger of God's message to be transmitted to mankind, and the second receiver is all mankind. Other than that, the narrative structure of the story of Musa in the Qur'ân has an ethical function. It brings spiritual-eschatological vision to mankind. Through interpersonal relation structure and the representation concept of time and place, the story of Musa gives theological and moral values. The one that distinguishes the narrative function of the story of Musa in the Qur'ân from the other stories created by people is the rhetoric clarity (al-bu'd al-bayânî). The Qur'ân always uses simple and meaningful rhetoric. Thus, in presenting the story of Musa, the Qur'ân only exposes important events that conform to religious purposes (al-ghard al-dinî).
\end{abstract}

Keywords: Narratorology; the story of Musa; the rhetoric clarity.

\section{Pendahuluan}

Kisah merupakan salah satu jenis prosa naratif (al-adab al-nathri). ${ }^{1}$ Kisah sudah ada sejak lama seiring dengan sejarah manusia di muka bumi, ${ }^{2}$ karena kisah menjadi salah satu media untuk mengungkapkan pikiran, perasaan dan isi hati. ${ }^{3}$

${ }^{1}$ Muhammad al-Tûnjî, al-Mưjam al-Mufașsal fì al-Adab, Vol. 2 (Beirut: Dâr al-Kutub al-'Ilmîyah, 1993), 706.

2 Aḥmad Abû Sa'd, Fann al-Qișsah (Beirut: Manshûrât Dâr al-Sharq al-Jadîd, 1959), 7.

3 al-Tûnjî, al-Mujjam al-Mufassal fî al-Adab, 707. 
Kisah dalam pengertian sastra modern didefinisikan sebagai narasi berbagai kejadian yang disusun berdasarkan urutan waktu. ${ }^{4}$ Ia seni memberi (form of giving), yaitu menyampaikan sesuatu ke hadapan publik; menjadi media untuk menanamkan tata nilai atau bahkan memaksakan (mendoktrinkan) segala sesuatu kepada yang lain. ${ }^{5}$

Eksistensi kisah dalam al-Qur'ân diproyeksikan demi tujuan mulia terkait dengan risalah yang diemban oleh Nabi Muhammad dan sekaligus sebagai bukti kenabian (dalâil al-nubumwah). ${ }^{6}$ Sayyid Quṭb berpendapat bahwa kisah-kisah al-Qur'ân, dalam segala objek, cara pemaparan dan penarasiannya tunduk dalam kepentingan agama Islam. Semua ini hampir dapat dilihat dalam keseluruhan kisah yang terdapat dalam al-Qur'ân.

Kisah Nabi Musa merupakan kisah yang paling banyak dimuat dalam al-Qur'ân. Kisah ini termaktub dalam lebih dari tiga puluh surat. Kisah-kisah al-Qur'ân menyuguhkan nilai-nilai teologis dan sekaligus nilai-nilai moralitas sosial. Nilai-nilai ini menjadi pesan yang hendak disampaikan dalam kisah Musa dalam al-Qur'ân. ${ }^{8}$

Untuk dapat menangkap makna dan pesan kisah Musa di dalam al-Qur'ân, dan bagaimana al-Qur'ân membangun suatu bentuk-makna baru dalam konteks keberlangsungan dakwah kenabian Muhammad, maka dibutuhkan analisis naratif terhadap bangunan naratif kisah tersebut.

Analisis naratif berpijak pada teori naratologi yang berfokus untuk menganalisis sesuatu yang berurutan, yang memiliki awalan dan akhiran atau awal-tengah-akhir. Oleh karena itu, analisis naratif terhadap kisah berarti membaca suatu cerita mengenai peristiwa melalui paragraf narasi yang disusun dengan merangkaikan kejadiankejadian yang berurutan. Teori naratologi berfokus untuk menganalisis sesuatu yang berurutan, yang memiliki awalan dan akhiran atau awal-tengah-akhir.

${ }^{4}$ E. M. Forster, Aspects of The Novel (London: Harcourt Inc., 1985), 30. Lihat juga Burhan Nurgiyantoro, Teori Pengkajian Fiksi (Yogyakarta: Gadjah Mada University Press, 2010), 91.

${ }^{5}$ Amy E. Spaulding, The Art of Storytelling (United Kingdom: The Scarecrow Press, 2011), 15.

${ }^{6}$ Sayyid Quṭ, al-Taswîr al-Fannî fî al-Qur'ân (Kairo: Dâr al-Ma'ârif, t.th.), 120.

${ }^{7}$ Ibid., 141-143.

8 Muhammad Aḥmad Khalaf Allâh, al-Fann al-Qasașî fî̀ al-Qur'ân al-Karîm (Kairo: Maktabat al-Nahḍah al-Miṣrîyah, 1951), 98-112. 
Analisis naratif terhadap kisah di dalam al-Qur'ân penting untuk dilakukan karena ia menyuguhkan pemahaman yang jauh melampaui atribut-atribut teologis yang kaku. Kisah-kisah para nabi dalam alQur'ân bukan sekadar persoalan iman dan kafir, kebaikan dan keburukan, kebenaran dan kebatilan, dan seterusnya, tetapi kisah itu membanjiri hati nurani manusia dengan mengajukan kepadanya suatu bangunan simbolis yang luas, dan mampu memberikan ilham kepada orang-orang yang beriman untuk berpikir dan bertindak.

Arkoun berpendapat bahwa kisah-kisah para nabi dalam al-Qur'ân menuntut adanya analisis secara naratif untuk menunjukkan bagaimana al-Qur'ân membangun suatu bentuk-makna baru yang mempunyai cara kerja yang khusus dalam bahasa Arab. ${ }^{9}$ Kisah-kisah al-Qur'ân secara umum dan kisah para nabi secara khusus, menyuguhkan kepada pembaca susunan dan relasi aktansial yang menjadi plot dasar, yang mampu menggerakkan kesadaran manusia terhadap kebenaran yang hakiki. Beberapa akademisi sudah pernah membahas tentang kisah-kisah dalam al-Qur'ân, antara lain: Aḥmad Abû Sa'd, ${ }^{10}$ 'Abd al-Karîm al-Khaṭib, ${ }^{11}$ Muḥammad Aḥmad Khalaf Allâh, ${ }^{12}$ Muhammad 'Âbid al-Jâbirî, ${ }^{13}$ Sayyid Quṭb, ${ }^{14}$ Shârif Mazârî, ${ }^{15}$ dan lain-lain.

\footnotetext{
${ }^{9}$ Ibid., 157.

10 Abû Sa'd memaparkan bahwa kisah dalam al-Qur'ân telah menggantikan tradisi cerita-cerita masyarakat Arab. Kisah-kisah al-Qur'ân menjadi titik awal dari lahirnya bentuk cerita yang artistik (suwar al-qașas al-fannî). Menurutnya, kisah-kisah al-Qur'ân dapat diklasifikasikan menjadi dua, yaitu kisah historis (al-qasas al-târîkhî) dan kisah tamthîlî. Sementara unsur-unsur yang terdapat dalam kisah-kisah al-Qur'ân adalah peristiwa (al-ḥadîthah), tokoh (al-shakhsîyah) dan gaya bahasa (al-uslüb). Lihat Sa'ad, Fann al-Qissah.

11 Buku ini adalah menyingkap kisah-kisah al-Qur'ân sebagai salah satu gaya alQur'ân dalam menyampaikan risâlah samâwîyah. Sudut pandang yang dipakai dalam kajian buku ini adalah kisah al-Qur'ân dilihat dari segi seni (artistik). Menurutnya, keartistikan kisah al-Qur'ân dicirikan oleh dua hal, yaitu autentik dan orisinal. Kisah al-Qur'ân itu autentik karena berbicara tentang kebenaran, dan orisinal karena kisah itu bersumber dari Allah. Selain itu, unsur-unsur yang membangun kisah-kisah alQur'ân juga dibahas secara detil. Lihat 'Abd al-Karîm al-Khațîb, al-Qașas al-Qur'ânî fî̀ Mantûqih wa Mafhûmih (Beirut: Dâr al-Ma'rifah, 1975).

12 Buku ini mengupas kisah-kisah al-Qur'ân melalui pendekatan sastra (al-manhaj aladabi). Salah satu hal yang mendorong Khalaf Allâh untuk menggunakan pendekatan sastra sebagai metodologi adalah bahwa sejauh ini mayoritas mufassir terjebak pada pendekatan sejarah dalam menafsirkan teks-teks kisah al-Qur'ân. Mereka membaca kisah-kisah dalam al-Qur'ân sebagaimana mereka membaca teksteks sejarah. Di samping itu, melalui pendekatan sastra ini Khalaf Allâh juga hendak
} 


\section{Struktur Kisah Nabi Musa dalam al-Qur'ân}

Tidak semua ayat menarasikan kisah Nabi Musa secara detail. Sebagian ayat yang menyinggung tentang Musa disebutkan dalam konteks sebagai pelajaran untuk diambil hikmahnya bagi umat Islam secara umum. Sementara sebagian besar ayat yang lain menarasikan kisah Musa secara eksplisit. Narasi kisah Musa dalam al-Qur'an hadir dalam bentuk yang fragmentatif. Tidak dihadirkan secara utuh, mulai awal sampai akhir, tetapi terbagi-bagi ke dalam bagian-bagian kecil. Kadang antara bagian yang satu dengan yang lain ditemukan perbedaan dan atau persamaan. Bagian-bagian dari kisah Musa dalam

menangkal kesalahan kaum Orientalis dalam memahami gaya bahasa dan teknik alQur'ân dalam mengonstruk sebuah kisah, sehingga mereka menganggap bahwa alQur'ân itu tidak valid dan merupakan karangan Nabi Muhammad. Lihat Khalaf Allâh, al-Fann al-Qasasî.

13 Buku ini membahas tentang kisah-kisah al-Qur'ân dengan menggunakan sudut pandang “al-Qur'ân menjelaskan dirinya sendiri” (al-Qur'ân yusharrị̣ ba'duh ba'dan). Dalam pasal ketiga dari buku ini, al-Jâbirî menjelaskan mengenai pentingnya memahami kisah-kisah al-Qur'ân berdasarkan urutan turunnya surat (tartîb al-nu₹̨û́), bukan urutan surat (tartîb al-suwar). Menurut al-Jâbirî, keberadaan kisah dalam alQur'ân memiliki keterkaitan erat dengan dakwah Nabi Muhammad. Dengan kata lain, hadirnya kisah-kisah al-Qur'ân mencerminkan perjalanan dakwah beliau Nabi Muhammad, misalnya kisah Nabi Musa lebih banyak dipaparkan dalam surat-surat Makkiyah. Fokus kajian al-Jâbirî dalam buku ini adalah melihat kisah-kisah al-Qur'ân sesuai dengan kronologi turunnya surat (tartîb al-nuzû́), yang dapat dikorelasikan dengan potret perjalanan dakwah Nabi Muhammad. Di sini, kajian mengenai kisahkisah al-Qur'ân jauh dari perspektif sastra atau seni. Lihat Muhammad 'Âbid alJâbirî, Madkhal ilâ al-Qur'ân al-Karîm, Vol. 1 (Beirut: Markaz Dirâsât al-Waḥdah al'Arabîyah, 2006).

${ }^{14}$ Buku ini merupakan buku lain yang mengkaji tentang kisah al-Qur'ân. Dalam pasal yang bertajuk al-Qisssah fì al-Qur'ân, ia dengan menggunakan pendekatan seni menegaskan bahwa kisah-kisah al-Qur'ân sepenuhnya tunduk dalam tujuan agama (al-gharḍ al-dînî). Menurutnya, kisah al-Qur'ân memiliki karakteristik cara pengungkapan yang beragam, di antaranya: 1) kisah dimulai dengan ringkasan cerita, 2) kisah dibuka dengan pemaparan tentang makna edukatif dari penceritaan, 3) kisah langsung dipaparkan dengan tanpa pembukaan atau ringkasan cerita, dan 4) kisah diungkapkan secara tamthîli. Lihat Quṭb, al-Taswîr al-Fannî.

15 Buku ini mengajak pembaca untuk mengkaji kisah-kisah al-Qur'ân dengan mengggunakan pendekatan teori sastra modern. Menurutnya, teori sastra modern tidak saja penting untuk membaca kisah al-Qur'ân tetapi juga mendapatkan pendasarannya dalam tradisi ulama klasik. Lihat Shârif Mazârî, Mustawayât al-Sard alI'jâzîi fî̀ al-Qișsah al-Qur'anîyah (Damaskus: Manshûrât Ittihâad al-Kuttâb al-'Arab, 2000). 
al-Qur'ân dapat diklasifikasikan ke dalam episode (mashhad) secara lebih jelas sebagaimana berikut:

\begin{tabular}{|c|l|}
\hline Episode & \multicolumn{1}{|c|}{ Deskripsi } \\
\hline I & $\begin{array}{l}\text { Kelahiran dan kehidupan Musa di istana raja Fir'aun di } \\
\text { Mesir }\end{array}$ \\
\hline II & $\begin{array}{l}\text { Musa membunuh salah seorang penduduk Mesir dan } \\
\text { melarikan diri menuju Madyan }\end{array}$ \\
\hline III & $\begin{array}{l}\text { Musa kembali ke Mesir dan diutus menjadi Rasul untuk } \\
\text { membebaskan Bani Israil dari kezaliman Fir'aun }\end{array}$ \\
\hline IV & Musa meninggalkan Mesir menuju Palestina \\
\hline V & Musa bertemu dengan Tuhan untuk kedua kalinya \\
\hline VI & Musa dengan kaumnya; pertemuan Musa dengan Khidir \\
\hline
\end{tabular}

Selanjutnya klasifikasi episode kisah Musa di dalam al-Qur'an dapat disimpulkan bahwa episode III tampak disebut lebih banyak dan lebih mewarnai dalam al-Qur'ân, disusul kemudian episode IV. Episode V disebut empat kali. Episode I disebut dua kali, sementara episode II dan episode VI diulang sebanyak tiga kali.

Ada enam surat antara lain, surat Ṭ̂ha, al-A'râf, al-Qașas, alNaml, al-Kahf dan al-Shu'arâ' yang memuat episode lebih lengkap dan rinci. Surat al-Qașaṣ memuat episode yang paling lengkap dari kisah Musa di antara surat-surat yang ada. Hal yang sama juga terdapat dalam surat Ṭâha, al-A'râf, al-Qaṣaṣ dan al-Shu'arâ'. Surat al-Naml memiliki narasi yang lebih rinci dalam mendeskripsikan penggalan episode III dari kisah Musa, sedangkan surat al-Kahf secara lebih spesifik mendeskripsikan cerita Musa dengan Nabi Khidir.

\section{Aspek Verba: Gaya Pengaluran dan Sudut Pandang}

Dalam cerita, alur atau plot merupakan suatu keharusan. Tanpanya, suatu cerita tidak akan dapat disebut cerita. Rangkaian peristiwa yang menghubungkan antara satu sama lain, membuat sebuah cerita menjadi ada. Oleh karena itu, dapat dikatakan bahwa alur (plot) merupakan tulang punggung dan inti dari cerita. Untuk dapat mengerti sebuah cerita, dibutuhkan pemahaman terhadap peristiwa-peristiwa yang mempertautkan alur, hubungan kausalitas dan keberpengaruhannya.

Suatu cerita dianggap bagus jika cerita itu dibangun oleh peristiwaperistiwa yang relevan. Peristiwa yang membangun cerita dianggap relevan apabila hubungan antara satu peristiwa dengan peristiwa yang lain bersifat kausal. Peristiwa kausal adalah peristiwa yang menyebabkan atau menjadi dampak dari berbagai peristiwa yang lain. 
Sebaliknya, peristiwa-peristiwa dalam cerita, yang tidak terhubung secara kausal dipandang irelevan terhadap alur. ${ }^{16}$

Sebagaimana diketahui, cerita Musa di dalam al-Qur'ân dipaparkan secara fragmentatif. Al-Qur'ân tampak menampilkan momenmomen (mashâbid) penting saja yang di dalamnya serangkaian peristiwa terjalin secara kausal; setiap adegan yang dilakukan oleh seorang tokoh mempengaruhi hubungannya dengan karakter-karakter yang lain.

Dalam episode (mashhad) pertama, cerita langsung dibuka dengan konflik batin yang tercermin dalam jiwa ibu Musa. Ibu Musa diliputi ketakutan dan kekhawatiran yang tinggi atas nasib bayinya (Musa kecil) karena kebingungan untuk menyelamatkannya dari kelaliman (kejaran) Fir'aun. Dalam kondisi seperti itu, Allah sebagai Narator (alqâss) hadir di dalam cerita; memberi ilham kepada ibu Musa untuk membuang bayinya ke dalam sungai. Peristiwa membuang bayi ke dalam sungai ini kemudian memicu peristiwa yang lainnya; bayi Musa ditemukan dan dipelihara oleh keluarga Fir'aun, ibu Musa mengutus saudara Musa untuk mencari kabarnya sehingga bayi Musa dapat kembali ke pangkuan sang ibu.

Permintaan Sang Narator kepada ibu Musa untuk tidak mengkhawatirkan bayi yang dibuang, menjadi terjawab dengan usulan istri Fir'aun untuk tidak membunuh bayi itu karena ia begitu menenteramkan hati dan mungkin mendatangkan manfaat.

Dalam Q.S. al-Qașaṣ [28]: 9 tersebut bahwa di pihak ibu Musa, rasa khawatir tetap saja menghantui dirinya, lebih-lebih setelah sang bayi lepas dari pelukannya. Untuk itu, ia mengutus saudara Musa supaya mencari tahu tentang nasib bayi yang sedang berada di lingkungan istana Fir'aun. "Ikutlah dia", itulah perintah ibu Musa kepada saudaranya.

Pada akhirnya, saudara Musa menunjukkan kepada istri Fir'aun tentang orang yang bisa menyusui bayi Musa, setelah dalam beberapa waktu yang cukup lama meronta-ronta kehausan dan kelaparan. Ini menjadi peristiwa yang sangat fungsional dalam alur kembalinya bayi Musa ke pangkuan ibunya.

Dalam episode (mashhad) kedua, Sang Narator (Allah) mengawali cerita dengan memberikan kesimpulan tentang tokoh Musa. Ketika

\footnotetext{
${ }^{16}$ Robert Stanton, Teori Fiksi, terj. Sugihastuti dan Rossi Abi al-Irsyad (Yogyakarta: Pustaka Pelajar, 2012), 26.
} 
Musa mencapai usia dewasa dan sempurna akalnya, Allah menganugerahkan kepadanya pengetahuan ( $\mathrm{i} / \mathrm{m}$ ) dan hikmah.

Selanjutnya, Sang Narator menggambarkan Musa memasuki kota Memphis. Di sana Musa menemui dua orang pemuda yang sedang bertengkar sehingga memaksa dirinya untuk menolong salah satunya; Musa memukulnya hingga meninggal dunia. Musa diliputi rasa takut. Rasa penyesalan terucap dalam bibirnya: "Ini adalah perbuatan setan. Sesungguhnya setan itu adalah musuh yang menyesatkan dan nyata". Musa pun berdoa: "Ya Tuhanku, sungguh aku telah menganiaya diriku sendiri, karena itu ampunilah aku". Pengakuan dan doa yang terucap dari bibir Musa ini merupakan wujud kedewasaannya dalam menghadapi realitas yang terjadi di sekelilingnya.

Peristiwa serupa hampir terulang di hadapan Musa. Ia kembali dihadapkan pada perselisihan antara dua orang pemuda. Salah satunya pemuda yang sebelumnya pernah ditolong. Hampir saja Musa memukul salah satu pemuda itu, kalau saja tidak ada teriakan seseorang yang mengabarkan bahwa penguasa berencana akan menangkap dirinya. Akhirnya, dengan diliputi rasa takut Musa melarikan diri menuju kota Madyan. "Ya Tuhan, selamatkanlah aku dari orang-orang yang zalim", pinta Musa kepada Allah.

Di kota Madyan, kedewasaan Musa juga diuji oleh dua perempuan penggembala ternak yang secara sengaja menghalangi perjalanannya. Kedua perempuan itu meminta tolong kepada Musa untuk mengambilkan air di tengah kerumunan penggembala laki-laki yang lain. Atas jasa Musa tersebut, sang ayah dari dua perempuan penggembala meminta dirinya untuk mengawini keduanya. Musa di mata dua perempuan penggembala dan ayahnya tampak sebagai sosok al-qawiy al-amin (perkasa dan terpercaya). Sifat ini semakin meneguhkan kedewasaan Musa sebagai orang yang dikarunia oleh pengetahuan dan bikmah sebagaimana dinyatakan di bagian awal cerita oleh Sang Narator (Allah).

Mencermati rangkaian peristiwa dalam dua mashhad di atas, dapat disimpulkan bahwa peristiwa-peristiwa yang terdapat di dalam cerita Musa terjalin secara kausal. Antara peristiwa yang satu dengan yang lain terkait secara fungsional sehingga membangun suatu alur yang logis dan bermakna. Peristiwa-peristiwa tersebut menampakkan alur yang lebih rekat dan padat.

Burhan Nurgiyantoro berpendapat bahwa peristiwa yang sangat menentukan dan mempengaruhi perkembangan alur disebut dengan 
peristiwa fungsional. Dalam sebuah cerita, kehadiran peristiwa fungsional menjadi suatu keharusan. Jika peristiwa fungsional dalam suatu cerita ditinggalkan, maka dapat dipastikan cerita itu akan menjadi kurang logis. Dengan demikian, peristiwa fungsional menjadi faktor dalam menentukan kelogisan sebuah cerita. Ketika peristiwa fungsional mendominasi dalam cerita, maka alur dari cerita cenderung beralur padat. ${ }^{17}$ Dua mashhad tentang cerita Musa tersebut di atas cenderung menunjukkan alur yang padat.

Pengaluran yang seperti itu juga dapat disaksikan dalam beberapa mashbad yang lain. Dalam mashhad cerita Musa kembali menuju Mesir untuk diutus menjadi rasul setelah memenuhi janji yang telah ditentukan kepada Nabi Shu'ayb, Musa melihat api dan kemudian mendatangi tempat api itu. Ketika sampai, Musa diseru oleh Allah, "Ya Musa, sesungguhnya Aku adalah Allah Tuhan semesta alam". Dalam mashbad ini, Sang Narator (Allah) kembali hadir ke tengah cerita; ia menjadi bagian dari dan terlibat dalam cerita.

Sang Narator (Allah) hadir ke tengah inti cerita dengan memerintahkan Musa untuk melemparkan tongkatnya yang kemudian berubah menjadi ular yang meliuk-liuk. Lalu Sang Narator menyuruh Musa untuk memasukkan tangannya ke dalam leher baju dan mengeluarkannya kembali, kemudian berubah menjadi cahaya putih.

Dalam Q.S. al-Qașaș [28]: 31-32 kemudian Sang Narator (Allah) secara langsung memerintahkan Musa untuk mendatangi Fir'aun dengan membawa mukjizat sebagai tanda atas kekuasaan-Nya. Kedatangan Musa tidak menjadikan Fir'aun untuk berpaling pada risâlah Allah. Antara Musa dan Fir'aun terjadi dialog yang sangat alot, sehingga terpapar berbagai peristiwa secara silih berganti. Serangkaian peristiwa terus berjalan hingga akhirnya para tukang sihir yang disewa oleh Fir'aun tunduk pada Musa dan sementara Fir'aun tetap tidak menerima dakwah Musa atau bahkan kemarahannya malah menjadijadi. Bahkan Fir'aun bersumpah akan memotong tangan dan kaki secara bersilang bagi mereka yang membangkang pada dirinya.

Peristiwa keluarnya Musa dan kaumnya dari Mesir menjadi awal ketegangan baru antara dirinya dengan Fir'aun setelah peristiwa tunduknya tukang sihir sewaan kepada Musa. Musa diseru oleh Sang Narator (Allah) untuk bersegera meninggalkan Mesir. Peristiwa ini memicu kemarahan Fir'aun sehingga ia memerintahkan bala tentaranya untuk mengejar dan menutup semua jalan keluar.

${ }^{17}$ Nurgiyantoro, Teori Pengkajian Fiksi, 118-119. 
Klimaksnya, Fir'aun beserta pasukannya mendapati Musa dan kaumnya di pinggir laut merah. Dalam situasi terjepit, Sang Narator (Allah) mewahyukan kepada Musa untuk memukul air laut sehingga terbelah dan menjadi jalan keluar bagi Musa dan kaumnya dari kejaran Fir'aun. Fir'aun mengejarnya dan kemudian dihempaskan ombak air laut. Fir'aun dan pasukannya pun mati tenggelam dalam lautan, sementara itu Musa dan kaumnya selamat.

Sampai di sini, mencermati alur cerita Musa dalam berdakwah kepada Fir'aun menjadi hal yang menarik bagi para pembaca. Pada awalnya, bayi mungil Musa harus diselamatkan dengan dibuang ke dalam sungai, sementara Fir'aun pada saat itu menjadi raja yang lalim dan berpengaruh kuat. Ini menjadi pembuka cerita. Sedangkan pada akhir cerita, kondisi Musa dan Fir'aun digambarkan secara berbalik, di mana Fir'aun ditenggelamkan di laut sementara Musa diselamatkan. Alur ini dapat digambarkan sebagaimana berikut:

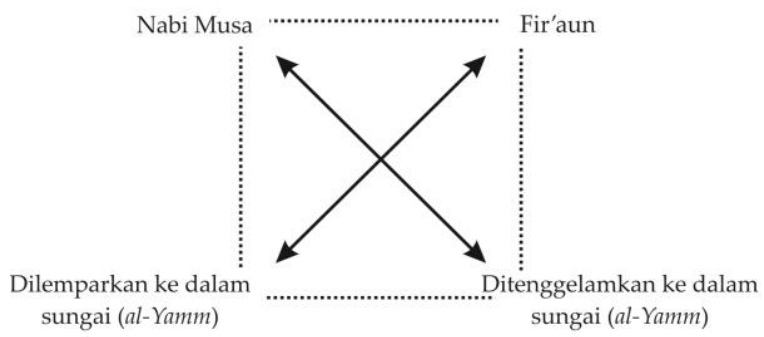

Bagan XI: Pola Alur/Relasi Tokoh Nabi Musa dengan Fir'aun

Terdapat titik temu di awal dan akhir cerita, antara peristiwa yang dialami oleh Musa dan Fir'aun. Musa dan Fir'aun sama-sama merasakan berada dalam ombang-ambing air sungai (laut); Musa dihanyutkan dalam sungai dalam rangka untuk diselamatkan, dan sebaliknya Fir'aun dihempaskan di dalam laut untuk diazab oleh Allah. Shârif Mazârî berpendapat bahwa model pengisahan seperti itu menjadi suatu kelebihan dari naratologi al-Qur'ân (al-sardîyah alQur'anîyah) yang berpijak pada prinsip dualisme (mabda' al-thunâ'iyah). ${ }^{18}$

Kata sungai (al-yamm) yang menjadi latar peristiwa menjadi faktor penting yang menggerakkan jalannya cerita. Pada bagian awal cerita, sungai (al-yamm) menjadi tempat penyelematan Musa dari bala tentara Fir'aun sementara sang ibu merasakan kekhawatiran yang luar biasa. Di sinilah alur cerita Musa mulai menampakkan ketegangan (suspen-

18 Mazârî, Mustawayât al-Sard al-I jầẑ, 67-68. 
si); suasana batin audien dipenuhi dengan ketegangan psikologis. Sedangkan pada bagian akhir cerita kata sungai (al-yamm) menjadi tempat kematian bagi Fir'aun. ${ }^{19}$

Dalam mashhad berikutnya, Musa digambarkan memenuhi undangan Sang Narator (Allah) untuk bertemu kedua kalinya. Dalam bagian ini, kehadiran Sang Narator di dalam inti cerita tetap sangat menonjol. Sang Narator menegaskan bahwa diri-Nya menjanjikan kepada Musa untuk bertemu dalam batas waktu yang ditentukan. Untuk memenuhi janji itu, Musa pun pamit dan menyerahkan kaumnya kepada Nabi Harun.

Sepulang dari bermunajat kepada Allah, Musa sangat marah kepada Nabi Harun karena mendapati kaumnya berpaling menyembah patung sapi. Intensi cerita mengalami ketegangan. Musa menarik kepala Harun dan membanting luhb-luh. Ketegangan mereda. Musa mengambil kembali luh-luh yang di dalamnya terdapat tulisan tentang petunjuk dan rahmat untuk orang-orang yang takut kepada Allah.

Teknik pengaluran padat dengan berbagai peristiwa fungsional sebagai pembangunnya, juga dapat ditemukan dalam mashbad cerita tentang perguruan Musa kepada Nabi Khidir. Dalam bagian ini, cerita dibuka dengan penggambaran jauhnya jarak yang ditempuh oleh Musa dengan ditemani pembantunya untuk bertemu dengan seorang guru, Nabi Khidir. Secara implisit, pengantar awal cerita ini mengisyaratkan akan kegigihan Musa untuk berguru kepada Khidir.

Cerita perguruan diawali ketika Musa merasa lapar dan meminta pembantunya untuk memberikan bekal makanan yang dibawa. Sang pembantu memberitahu bahwa ikan sebagai bekal yang dibawanya, telah hilang saat mereka berdua berlindung di batu. Musa pun menegaskan bahwa tempat hilangnya ikan itulah tempat yang sedang dicari.

Dalam Q.S. al-Kahf [18]: 63-64 disebutkan bahwa di tempat hilangnya ikan itu awal perguruan Musa kepada Khidir dimulai. Pada mulanya niat Musa untuk berguru ditolak oleh Khidir tetapi berkat desakan dan kegigihan Musa akhirnya dia diterima dengan syarat Musa harus mampu bersabar selama berguru dengannya; tidak boleh bertanya sedikitpun.

\footnotetext{
${ }^{19}$ Muhammad 'Abd Allâh 'Abduh Dabûr, "Usus Binâ' al-Qișṣah min al-Qur'ân alKarîm: Dirâsah Adabîyah wa Naqdîyah” (Disertasi--Jâmi'at al-Azhar, Kairo, 1996), 156.
} 
Perguruan terus berlanjut. Mereka berdua meneruskan perjalanan hingga mereka menaiki sebuah perahu dan Khidir melobanginya; mendapati seorang bocah dan Khidir malah membunuhnya; mendapati sebuah tembok (dinding) rumah yang hampir roboh dan Khidir menegakkannya. Selama perjalanan itu, Musa gagal berguru karena tidak memenuhi janji untuk tidak bertanya. Akhirnya Nabi Khidir memutuskan untuk berpisah dengan Musa. Cerita pun ditutup dengan penjelasan Khidir kepada Musa tentang peristiwa yang telah diperbuat sebelumnya.

Begitulah peristiwa-peristiwa itu membangun cerita Musa mulai awal hingga akhir. Peristiwa itu terlihat sangat padat dan rekat, membuat alur cerita menjadi logis. Jenis plot padat inilah-sekali lagiyang membangun cerita Musa. Setiap peristiwa yang ditampilkan dalam cerita Musa ditampilkan terasa penting dan berperan menentukan dalam rangkaian cerita. Hubungan antar-peristiwa dalam setiap mashbad (episode) terjalin secara erat, sehingga memaksa para pembaca untuk mengikutinya secara terus-menerus.

Sebagai konsekuensi dari alur yang padat, cerita Musa dalam alQur'ân ini kurang menampilkan gambaran-gambaran atau adeganadegan penyituasian yang berkepanjangan. Karena hal itu akan dapat mengurangi dan mengganggu konsentrasi pembaca terhadap cerita. Al-Qur'ân menampilkan cerita Musa dalam bagian-bagian peristiwa yang bermakna.

Selain memiliki alur, sebuah cerita pasti memiliki pengisah cerita atau narator. Narator dalam cerita dimaksudkan sebagai suatu metode narasi yang dianggap sangat menentukan sudut pandang terhadap penyampaian sebuah cerita. Dengan kata lain, sebuah cerita akan dapat diketahui posisinya melalui sudut pandang Sang Narator.

Sudut pandang tidak bisa dipisahkan dari narator (pengisah). Sudut pandang dapat dianggap sebagai sebuah strategi yang digunakan oleh seorang narator dalam menyampaikan cerita. Melalui sudut pandang gagasan sebuah cerita ditampilkan dan dipahami lebih jelas. ${ }^{20}$

Cerita Musa di dalam al-Qur'ân ini menggunakan sudut pandang "akuan". Dalam sudut pandang ini sang pencerita (narator) berada di dalam cerita; di dalamnya sang pencerita bisa menjadi tokoh. Sudut pandang "akuan" bisa disebut dengan pencerita "akuan". Di dalam cerita Musa, yang dimaksud dengan pencerita "akuan" tidak lain

20 Albertine Minderop, Metode Karakterisasi Telaab Fiksi (Jakarta: Yayasan Pustaka Obor Indonesia, 2011), 87-88. 
adalah Allah (Sang Narator), di mana Allah menggunakan kata Aku/Kami dalam menyampaikan cerita dan terlibat langsung dalam berbagai peristiwa di dalamnya. Allah sebagai Sang Narator pun memiliki pengetahuan yang melampaui tokoh-tokoh cerita. Sang Narator bergerak secara bebas dari satu tokoh ke tokoh yang lain, dan bahkan dari satu ruang dan waktu tertentu ke dalam ruang dan waktu yang lain. Sang Narator menjadi pemegang otoritas dalam menentukan kebenaran atau kesalahan dalam cerita.

Dalam cerita Musa, Sang Narator (Allah) nampak meneguhkan diri-Nya sebagai tokoh yang memberikan ilham atau wahyu kepada tokoh cerita yang lain, dan darinya cerita itu digerakkan. Sang Narator menjadi tokoh yang menggerakkan tokoh lainnya; seolah tidak ada jarak antara keduanya.

Q.S. al-Qașaṣ [28]: 7 merupakan pembuka dari cerita Musa saat masih bayi. Sang Narator (Allah) tampak menjadi tokoh yang memberi ilham kepada ibu Musa untuk membuang bayi Musa ke dalam sungai, bahkan Dia menjamin keselamatannya dan menjadikannya sebagai rasul. Sang Narator lebih tahu dari pada tokoh yang lain. Sang Narator memberi perintah secara langsung kepada ibu Musa dengan kata "susuilah" dan "jatuhkanlah". Antara Sang Narator dengan ibu Musa seolah tidak ada jarak; sama-sama terlibat dalam berlangsungnya peristiwa yang terjadi.

Isyarat Sang Narator untuk memberitahu kepada pembaca tentang karakter dan status tokoh Musa kadang hadir melalui kesimpulan atau statemen singkat. Hal ini dapat dilihat saat Sang Narator memberikan status Musa sebagai sosok yang telah dianugerahi pengetahuan dan hikmah. Di sini, Sang Narator-sekali lagi-menunjukkan perannya sebagai "Pemberi" pengetahuan dan ḩikmah itu. Âtaynâh ḥukman wa ilman (Kami berikan kepadanya hikmah dan pengetahuan), firmannya. Anugerah pengetahuan dan bikmah menjadi petanda bahwa Musa telah mencapai usia matang dalam bersikap dan bertindak.

Statemen Sang Narator seperti itu kemudian disusul dengan peristiwa yang menunjukkan kematangan berpikir dan bertindak Musa. Peristiwa itu adalah sikapnya dalam menghadapi pertengkaran antara dua orang pemuda ketika memasuki kota Memphis (Mesir). Atas keterlibatannya dalam menolong salah satu pemuda yang berseteru tersebut (dengan memukul salah pemuda itu), Musa merasa telah berbuat zalim. Ia merasa sangat menyesal, dan berdoa meminta ampun dan bimbingan dari Allah. Hal yang sama juga hampir terjadi 
ketika Musa kembali menyaksikan pertengkaran antara dua pemuda sebagaimana saat awal memasuki kota Memphis. Tetapi Musa bisa menahan diri, dan kemudian meninggalkan kota Memphis menuju Madyan.

Sang Narator juga memaparkan peristiwa lain dari sikap kedewasaan Musa, yaitu saat perjalanannya terhalang oleh dua perempuan yang sedang menggembala ternak. Musa membantu mengambil air untuk binatang ternak yang digembalakan oleh kedua perempuan itu. Karena karakternya yang al-qawîy al-amin (perkasan dan dapat dipercaya) itulah, Musa kemudian dijodohkan dengan kedua perempuan itu.

Teknik penceritaan seperti ini dapat disebut dengan teknik deduktif di mana cerita dimulai dengan gambaran umum dan kemudian disusul dengan detail-detail peristiwa. Sang Narator memulai cerita dengan "Kami berikan kepadanya (Nabi Musa) b̧ikmah dan pengetahuan", kemudian setelahnya menggambarkan peristiwaperistiwa partikular yang menunjukkan tingkat kematangan berpikir dan bersikap seorang Musa yang menjadi tokoh utama.

Pada mashhad lain, Sang Narator hadir dengan menyapa para pembaca terlebih dahulu atau mengingatkan pembaca pada peristiwa yang sudah berlalu. Di sini, Sang Narator sejenak keluar dari dalam cerita, masuk ke dalam ruang pembaca. Dia membuka cerita sejenak kemudian masuk kembali ke dalam inti cerita.

Dalam potongan cerita al-Qașaṣ [28]: 29-32, Sang Narator (Allah) mengingatkan kembali kepada pembaca bahwa Musa telah menyelesaikan janjinya kepada Nabi Shu'ayb dalam batas waktu yang telah disepakati. Ketika batas waktu itu habis, Musa—seperti digambarkan oleh Sang Narator-berangkat menuju Mesir. Di tengah jalan, Musa melihat api di lereng gunung dan mendekatinya. Ketika sampai di tempat api, Musa diseru oleh Allah. Di sini, Sang Narator-yang sebelumnya berada di luar cerita - tiba-tiba masuk ke dalam inti cerita. Bahkan Sang Narator menjadi tokoh bersama-sama dengan Musa. Maka, terjadilah dialog antara Allah dan Musa. Musa diperintahkan untuk melemparkan tongkatnya yang kemudian berubah menjadi seekor ular. Kemudian ia disuruh untuk memasukkan tangannya ke dalam leher baju lalu dikeluarkan kembali dan berubah menjadi bercahaya putih.

Keterlibatan Sang Narator dalam inti cerita juga nampak jelas dalam narasi cerita Musa ketika Allah memberi isyarat kepadanya 
untuk segera pergi menemui Fir'aun. Saat diperintahkan untuk pergi menghadap Fir'aun, Musa minta kepada Sang Narator (Allah) untuk ditemani oleh saudaranya Nabi Harun. Kemudian Sang Narator kembali masuk ke dalam inti cerita. Namun ketika Musa sudah berhadap-hadapan dengan Fir'aun, Sang Narator tiba-tiba menghilang dari jalannya peristiwa.

Dalam narasi cerita perguruan Musa dengan Khidir, kehadiran Sang Narator sedikit agak samar. Sang Narator tidak terlibat secara langsung dalam peristiwa cerita. Jika di dalam narasi cerita sebelumnya Sang Narator menegaskan keterlibatan diri-Nya secara langsung melalui statemen-statemen yang tegas, seperti wa awhaynâ ilâ umm Mûsâ an ardịih, âtaynâh hukeman wa ilman, wa an alqi așâk, usluk yadak ilâ jaybik, wa awhaynâ ilâ Mûsâ an asri bi íbâdî, wa wấadnâ Mûsâ dan seterusnya, tetapi dalam cerita perguruan Musa dengan Khidir, Sang Narator hanya menegaskan bahwa seorang hamba yang ditemui oleh Musa itu adalah hambanya Sang Narator yang telah dikaruniai oleh Sang Narator rahmat dan ilmu. Dalam detail peristiwa selanjutnya, Sang Narator berada di luar inti cerita.

Dari uraian mengenai bagaimana narator menyampaikan cerita tersebut di atas, maka dapat ditegaskan kembali bahwa narasi cerita Musa ini menggunakan sudut pandang "akuan" atau pencerita "akuan". Implikasi dari sudut pandang seperti ini adalah bahwa (a) narator tetap ada saat peristiwa dalam cerita setelah terjadi, sedang terjadi dan sesudah terjadi, dan ia lebih tinggi dari dan melampaui ruang cerita; (b) narator menjadi pemegang otoritas tertinggi dalam menentukan apa yang benar dan yang salah, serta apa yang baik dan yang buruk; dan (3) pembaca di hadapan narator menempati posisi sebagai subjek yang pengetahuannya lebih rendah.

Meskipun Sang Narator memperlihatkan keterlibatannya di dalam cerita, tetapi ia tidak sekadar membicarakan diri-Nya sendiri. Ia tidak sekadar menarasikan seorang tokoh begitu saja sehingga melahirkan rasa bosan di benak pembaca, atau sekadar memaparkan narasi yang kering. Dalam cerita Musa di dalam al-Qur'ân ini, dialog menjadi sarana untuk menghidupkan narasi penceritaan sehingga mampu menembus pikiran, perasaan, gejolak dan kondisi batin pembaca. Dialog di dalam cerita Musa ini juga menjadikan suasana penceritaan menjadi semakin hidup. Masing-masing tokoh dalam cerita memantapkan perannya, dan darinya keterkaitan antarsatu peristiwa dengan peristiwa yang lain semakin tampak nyata. 
'Abd Allâh 'Abduh berpendapat bahwa dialog (ḥiwâr) merupakan salah satu unsur penting yang memiliki pengaruh dalam menggambarkan dan mengembangkan peristiwa dalam cerita. ${ }^{21}$ Dialog di dalam cerita-cerita al-Qur'ân menjadi sarana untuk melukiskan gejolakgejolak kejiwaan tokoh kisahnya yang menggerakkan satu peristiwa ke peristiwa berikutnya dengan sangat apik dan rapi.

Dialog dalam cerita Musa di dalam al-Qur'ân dapat dilihat dalam setiap mashhad, sejak penggambaran bayi Musa dalam gendongan ibunya sampai Musa berguru kepada Khidir. Dialog itu berlangsung antara Sang Narator dengan tokoh-tokoh seperti ibu Musa dan Musa, atau antar-sesama tokoh dalam cerita. Dialog-dialog itu membuat cerita semakin hidup dan mengesankan di hadapan pembaca.

Meskipun dialog bukan merupakan unsur prioritas satu-satunya dalam cerita Musa khususnya, dan cerita-cerita al-Qur'ân pada umumnya, namun kehadirannya tetap sangat penting. Dialog selalu hadir hampir dalam setiap cerita Musa dengan tetap menjaga keseimbangan cerita. Kehadiran dialog dalam narasi cerita Musa tidak mengurangi kualitas jalannya penceritaan, bahkan narasi penceritaan tetap berjalan sangat apik dan luwes, jauh dari kekakuan dan kebuntuhan.

Muhammad 'Abd berpendapat bahwa cerita Musa dibangun oleh tiga unsur penting, yaitu peristiwa (al-hadath), tokoh (al-shakhsîyah), serta dialog dan pemaparan (al-hiwâr wa al-sard). Unsur-unsur ini cukup dominan dalam dalam menggerakkan dan menghidupkan setiap bagian cerita Musa. ${ }^{22}$ Al-Qur'ân menggunakan unsur-unsur tersebut dalam cerita secara proporsional sehingga terbangun keseimbangan dalam narasi penceritaannya; cerita dinarasikan sesuai dengan tujuan agama dan bagian-bagian yang tidak penting ditinggalkan sehingga fungsi naratifnya semakin mudah ditangkap oleh pembaca. Ini menjadi keistimewaan naratif al-Qur'ân yang tidak bisa dibantah. AlQur'ân menggunakan prinsip ekonomis-artistik (al-iqtișâd al-fannî) dalam mendeskripsikan cerita. ${ }^{23}$

\section{Aspek Semantik: Kisah Nabi Musa sebagai Teks Pembebasan}

Sudah mafhum bahwa surat-surat dalam al-Qur'ân jarang membentuk satuan-satuan teks yang homogen. Seringkali, teks-teks

\footnotetext{
${ }^{21}$ Muhammad 'Abd Allâh 'Abduh, Usus Binâ' al-Qișsah li al-Qur'ân (Kairo: Jâmi'at alAzhar, 1996), 211.

22 Dabûr, “Usus Binâ’ al-Qișṣah”, 157.

${ }^{23}$ Ibid., 337.
} 
itu menjajarkan ayat-ayat yang berbeda sesuai dengan kandungan dan bentuknya, konteks dan waktu turunnya, serta situasi wacananya. Dalam penjajaran ayat seperti itulah, cerita-cerita dalam al-Qur'ân ditampilkan sehingga tampak sepenggal-penggal. Meskipun demikian, hal itu tidak menutup kemungkinan untuk menemukan suatu gagasan sentral yang saling terhubung antara satu bagian dengan bagian yang lain.

Dalam kaitannya dengan cerita, al-Qur'ân menegaskan tujuan dari penyebutan kisah adalah supaya umat manusia dapat mengambil 'ibrah dan hikmah yang terdapat di dalamnya. Tujuan mulia ini tidak lepas dari tujuan agama Islam. Dengan demikian dapat dikatakan, bahwa kehadiran cerita di dalam al-Qur'ân tidak dapat dilepaskan dari suatu tujuan mulia, dan dalam kerangka suatu tujuan mulia inilah cerita digunakan dalam al-Qur'ân.

Bagus Takwin berpendapat bahwa setiap cerita memiliki dimensi etis. Sistem nilai etis dipaparkan melalui alur cerita. Tokoh-tokoh dan peristiwa yang dipaparkan dalam cerita merefleksikan sebuah makna sehingga pembaca dapat memahaminya, dan pada saat yang sama mengundang pembaca untuk mengevaluasi karakter-karakter yang dikisahkan. Melalui cerita, pembaca dapat mengevaluasi diri sendiri dan orang lain lewat tokoh-tokoh dan tindakannya. Cerita menyediakan ruang bagi pembaca untuk bertanggungjawab secara individu dan terlibat bersama orang lain dalam mewujudkan kehidupan yang lebih baik bagi semua orang. Singkatnya, penceritaan membantu untuk mengembangkan sebuah sistem nilai etis. ${ }^{24}$

Nilai etis sebagaimana yang disebut oleh Bagus Takwin itu dapat disinkronkan dengan ‘ibrah dalam istilah al-Qur'ân. Jika di dalam alQur'ân disebutkan bahwa dalam cerita-cerita para Nabi atau umat terdahulu terdapat ibrah, maka itu artinya cerita tersebut melalui struktur naratif yang disuguhkan memberikan makna kepada tindakan manusia; mengandung konsep-konsep yang terangkai menjadi jalinan makna. Oleh karena itu, cerita di dalam al-Qur'ân menjadi salah satu sarana untuk mendakwahkan agama. Al-Qur'ân menggunakan cerita untuk menyampaikan nilai-nilai mulia dalam rangka memperbarui kesadaran keagamaan umat manusia.

Tak diragukan bahwa diskursus al-Qur'ân telah membangun suatu bentuk makna baru melalui cara kerja yang khas dalam bahasa Arab.

24 Bagus Takwin, Psikologi Naratif: Membaca Manusia sebagai Kisah (Yogyakarta: Jalasutra, 2007), 17-18. 
Bentuk makna ini-menurut Arkoun-memanifestasikan diri dalam dua kerangka, yaitu struktur hubungan interpersonal dan kerangka representasi ruang-waktu. ${ }^{25}$ Setidaknya, dalam kerangka seperti itulah, makna dan fungsi struktur naratif cerita Musa di dalam al-Qur'ân dapat dipahami.

Struktur naratif cerita Musa di dalam al-Qur'ân tidak sekadar penggambaran mengenai rangkaian peristiwa yang luar biasa, tokohtokok mulia dan atau situasi-situasi yang dramatis demi tujuan mainmain dan estetis. Cerita itu melahirkan nilai baru bagi sejarah umat manusia, dan dilahirkan oleh sejarah yang konkrit. Ia mengajukan suatu pengalaman individu yang menyuguhkan satu kesatuan makna dan kesadaran secara terus-menerus.

Dalam kerangka struktur hubungan interpersonal, struktur naratif Musa memerikan adanya suatu hubungan aktansial, yaitu hubungan antara pengirim-narator (Allah), penerima-penyampai (nabi) dan penerima pesan (manusia). Pengirim-narator adalah Allah yang telah berbicara dan menciptakan kejadian-kejadian, yang harus dipatuhi oleh semua manusia, sementara Musa/Khidir tidak lain adalah hamba-hamba yang membantu tindakan Allah dalam mewujudkan visi keselamatan dunia dan akhirat; Fir'aun prototipe keburukan yang tidak setia pada panggilan Tuhan. Sedangkan semua manusia menjadi penerima kebaikan dan kasih sayang Tuhan, yang harus tunduk dan patuh kepada-Nya dalam wujud tindak kebaikan yang nyata.

Allah memperkenalkan diri sebagai Narator (al-qâs.s) yang meliputi seluruh ruang dan waktu dengan kehendak dan pengetahuan-Nya yang tidak terbatas. Semua yang dikatakan-Nya menegaskan transendensi dan keagungan diri-Nya dalam hubungannya dengan keagungan "engkau" yang diajak bicara oleh-Nya. Seorang utusan (Nabi) adalah penerima pesan yang dimuliakan dan diagungkan oleh narator-pengirim; ia bukan penerima pesan yang pasif tetapi mengekspresikan diri sebagai pengirim yang bertanggungjawab untuk menyampaikan pesan kepada umat manusia.

Menurut Arkoun, susunan aktansial seperti itu, sebagaimana yang terdapat dalam cerita-cerita al-Qur'ân, merupakan alur (plot) dasar yang bersifat kontinu. Jalinan aktansial itu mengungkapkan suatu ketegangan antara sejarah teladan yang diarahkan kepada masa depan eskatologis (al-ma'âd) yang abadi, dan sejarah duniawi yang profan dan

${ }^{25}$ Mohammed Arkoun, Pemikiran Arab, terj. Yudian Wahyudi (Yogyakarta: Pustaka Pelajar, 1996), 7. 
tanpa perspektif; kekuasaan Tuhan yang abadi dan kekuasaan Fir'aun yang tak langgeng. ${ }^{26}$

Sementara itu, cerita Musa menentukan persepsi manusia dalam koordinat ruang-waktu yang ditentukan dengan baik. Alam dunia dan segala isinya merupakan perwujudan dari kreativitas Allah. Segalanya di dunia tidak ada yang kekal. Ia menjadi tanda-tanda kebesaran-Nya. Manusia di muka bumi hanyalah ditunjuk sebagai wakil Tuhan (khaliffah Allâh). Allah adalah Penguasa segala yang ada di langit dan bumi (Rabb al-samâwât wa al-ard).

Oleh karena itu, hakikatnya segala yang dimiliki oleh manusia di muka bumi bukanlah miliknya yang sesunguhnya; merupakan anugerah dan nikmat yang diberikan oleh Allah kepadanya. Atas pemberian nikmat itu, seseorang harus tunduk dan bersyukur kepadaNya. Jika Fir'aun memiliki kekayaan (istana dan seluruh isinya), maka itu hanyalah bersifat semu, bukan miliknya yang sebenarnya, bersifat sementara dan hanya warisan dari Allah.

Kerangka ruang dan waktu itu juga tampak terlihat jelas dalam cerita perguruan Musa dengan Khidir. Melalui Khidir, seorang hamba yang dipilih dan diberi pengetahuan oleh Allah. Musa mencerminkan ruang keterbatasan dalam hal ilmu pengetahuan. Sang pemilik pengetahuan mutlak adalah Allah yang telah menganugerahi seorang hamba saleh, Khidir. Segala yang ada di dunia bersifat terbatas dan fanẩ, tidak ada yang kekal dan absolut.

Di sini, dalam struktur naratif cerita Musa kerangka ruang dan waktu menemukan tempatnya. Ruang dan waktu itu mengisyaratkan suatu kerangka konkret mengenai visi eskatologis dan perjanjian iman ('ahd mîthâq) antara Tuhan dan hamba. Dalam kerangka inilah, hubungan antara Tuhan dan hamba ditempatkan secara timbal-balik.

Singkatnya, kerangka ruang dan waktu dalam cerita para Nabi mengisyaratkan visi spiritual yang merujuk pada tiga tingkatan hierarki, yaitu kehidupan dunia merupakan waktu yang pendek di mana seorang hamba diuji oleh Allah (ujian dan penderitaan yang dialami oleh Musa dalam menjalankan dakwah kepada Fir'aun), waktu kematian yang tidak satupun orang dapat mengetahuinya, dan kehidupan kekal (al-hayâh al-khâlidah) di surga yang diharapkan oleh setiap manusia. Wacana al-Qur'ân menampilkan visi spiritual ini

${ }_{26}$ Mohammed Arkoun, Berbagai Pembacaan Quran, terj. Machasin (Jakarta: INIS, 1997), 157-158. 
melalui cerita-cerita para nabi untuk mengarahkan manusia pada kesadaran eskatologis. ${ }^{27}$

Lebih jauh, Arkoun menjelaskan bahwa sejarah para nabi tidaklah mengajukan model-model etis yang sederhana. Menghadirkan kembali sejarah para nabi terdahulu berarti mengajak memori seseorang untuk mengingat kembali perjuangan dan kemenangan para nabi, kegagalan dan perlawanan yang dilancarkan oleh kaum-kaum yang menentangnya. Hal ini merupakan cara untuk mengaktualkan kembali situasisituasi paradigmatis dari sejarah penyelamatan umat manusia. Situasi paradigmatis ini tidak dapat memberikan arti kecuali dengan membawa persepsi-kesadaran manusia ke dalam simbolisme tentang hidup dan mati, keselamatan dan hukuman, kegembiraan dan kesedihan, kebenaran dan kebatilan, dan seterusnya. ${ }^{28}$

Cerita Musa menyuguhkan sebuah diskursus naratif tentang keimanan dan kekafiran, keselamatan dan hukuman, serta hidup dan mati. Terkait cerita Musa, al-Qur'ân secara tegas memaparkan diskursus keimanan dengan ḅukm (kebijaksanaan), ílm (pengetahuan), amin (beriman/percaya), sabbạ̣ (bertasbih), dhakar (mengingat), 'aqal (berpikir), sabar (bersabar), ista'ân (meminta pertolongan kepada Allah), așlặ (berbuat kebaikan), dan ittaqâ (bertakwa); diskursus kekafiran dengan khâti'în (berbuat kesalahan besar), taghâ (melewati batas), kâfirin (berbuat ingkar), qatta'a (memotong/menganiaya), sallab (menyalib/menganiaya), qatal (membunuh), âshâa (menyakiti), istakbar (bersikap sombong), mujrimin (melakukan kesalahan), istad'af (memperlemah), mufsidin (berbuat kerusakan), yankus (mengingkari), dan zulm (kezaliman). Diskursus keselamatan diilustrasikan dengan menggunakan kosa kata anjaynâ Mûsâ wa man ma'ah (Kami selamatkan Musa dan orang-orang yang bersamanya); sementara diskursus hukuman digambarkan dengan yublik 'adwnwakum (Dia meminasakan musuh-musuhnya), akbadhnâ bi al-sinîn wa naqs min al-amwâl (Kami mendatangkan musim kemarau dan kekurangan buah-buahan), arsalnâ 'alaybim al-tûfân wa al-jarâd wa al-qummâl wa al-dafâdi' wa al-damm (Kami kirimkam angin topan, belalang, kutu, katak dan darah), dan aghraqnâ al-âkharîn (Kami tenggelamkan yang lain). Diskursus hidup dan mati diilustrasikan dengan al-dunyâ: al-samâwât wa al-ard (kehidupan dunia) dan al-sấah (hari kiamat).

27 Arkoun, Pemikiran Arab, 10-11.

28 Arkoun, Berbagai Pembacaan Quran, 158. 
Struktur narasi kisah Musa di dalam al-Qur'ân memperlihatkan diskursus pertentangan antara kebenaran (al-haqq) melawan kebatilan (al-bâtii). Hal ini tampak dalam setiap episode pengkisahan yang digambarkan dalam al-Qur'ân. Musa dan kaumnya dengan berbagai karakter yang diperankan merepresentasikan kebenaran, sementara Fir'aun dan para pendukungnya dengan berbagai karakter yang melekat padanya mewakili mengejawentahkan nilai-nilai kebatilan. Di sini, kisah Musa di dalam al-Qur'ân menampakkan diskursus naratif yang konsisten. Selanjutnya, relasi oposisi biner dalam kisah Musa dapat digambarkan sebagaimana berikut:

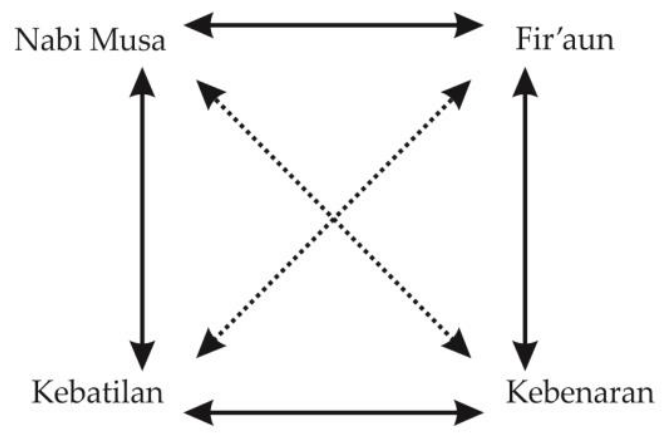

Bagan XII: Diskursus Naratif dalam Kisah Nabi Musa

Sampai di sini dapat dijelaskan bahwa struktur naratif Musa dibangun oleh sebuah susunan hubungan yang tidak berubah, yaitu pencerita-pencipta-pengirim (Allah) yang menyampaikan pesan kepada penerima pertama (Nabi Muhammad); penerima pertama menjadi penutur untuk menyampaikan pesan kepada penerima kedua (semua manusia). Jalinan hubungan ini membentuk sebuah komunikasi yang sarat dengan makna di mana ujaran-ujaran dan kejadian-kejadian di dalamnya menyuguhkan nilai etis dan pengalaman kehidupan yang mesti dihayati. Jalinan yang membentuk struktur naratif itu menyuguhkan kepada manusia cara untuk mengonstruki dunia.

Sebagai bagian dari diskursus al-Qur'ân, cerita Musa telah menjadi salah satu media dakwah Nabi Muhammad. Cerita Musa banyak mewarnai dakwah Nabi Muhammad. Hal ini terbukti dengan pengulangan cerita tersebut dalam al-Qur'ân; penyebutan cerita Musa melebihi cerita para nabi yang lain. Penyebutan ini musti memiliki signifikansi bagi dakwah yang dilakukan oleh Nabi Muhammad, terlepas visi spiritual-eskatologis_-sebagaimana yang disebut oleh 
Arkoun —atau nilai etis yang hendak disampaikan kepada umat manusia.

Dalam konteks dakwah Nabi Muhammad, cerita Musa menjadi media berbagi pengalaman dan penghayatan. Pengalaman dan penghayatan itu hadir dalam bentuk narasi kejadian yang tersusun secara sekuensial. Dengannya, tindakan teman dan kerabat, individuindividu dan kelompok-kelompok, serta institusi-institusi di ruang publik dapat dimaknai. Atau dengan kata lain, struktur naratif bisa memberikan makna kepada tindakan manusia.

Muhammad 'Imârah berpendapat bahwa cerita Musa dalam alQur'ân memperlihatkan beberapa sisi dakwah yang cukup beragam. Cerita itu menunjukkan sisi perlawanan terhadap kesewenangwenangan seseorang yang mentahbiskan dirinya sebagai tuhan, pembebasan Bani Israil dari penyembahan terhadap Fir'aun, perjuangan melawan kekufuran Bani Israil, ketauhidan dan sharî‘ yang dibawa oleh Musa. Semua sisi cerita ini memiliki kemiripan dengan sisi dakwah yang dilakukan oleh Rasulullah sebagai nabi akhir zaman. $^{29}$

Pendapat yang diutarakan oleh 'Imârah tersebut sejalan dengan pandangan Muhammad 'Âbid al-Jâbirî. Al-Jâbirî menjelaskan bahwa cerita-cerita dalam al-Qur'ân menjadi strategi dakwah Nabi Muhammad. Kehadiran cerita itu memiliki korelasi dengan situasi dan tantangan yang dihadapi oleh Nabi Muhammad. Cerita Musa dalam al-Qur'ân juga mengisyaratkan suatu fase dakwah yang dilaksanakan di tengah masyarakat atau kelompok pengikut agama/keyakinan pada saat itu. ${ }^{30}$

Lebih jauh al-Jâbirî menguraikan bahwa cerita Musa dalam alQur'ân hadir di saat Rasulullah mendapat tantangan dan cobaan dari masyarakat Quraish dan umat Yahudi; tekanan yang dilakukan oleh para elite suku Quraish (al-mala' min quraysh) dan bantahan umat Yahudi mengenai masalah-masalah yang sudah ada dalam kitab mereka. Tekanan elite Quraish terhadap Rasulullah dapat disinkronkan dengan tekanan yang dihadapi oleh Musa dari Fir'aun dan para pengikutnya di satu sisi, sementara di sisi lain potongan cerita Musa dalam beberapa surat menjadi jawaban atas sanggahansanggahan dari umat Yahudi. Kehadiran cerita Musa dalam al-Qur'ân

\footnotetext{
${ }^{29}$ Maḥmûd Muhammad Muhammad 'Imârah, Fiqh al-Da'wah min Qișsah Musa 'alayh al-Salâm (Kairo: Maktabat al-Imân, 1997), 35-36.

${ }^{30}$ al-Jâbirî, Madkbal ilâ al-Qur'ân, 420-422.
} 
ini juga sekaligus merupakan bentuk respons terhadap situasi dan tantangan baru yang berlangsung dan dihadapi oleh Nabi Muhammad dalam rentang sejarah perjuangan dakwahnya. ${ }^{31}$

Dakwah yang dilakukan oleh Rasulullah terjadi dalam dua fase, yaitu Makkah dan Madinah. Kisah Musa diulang dalam surat-surat Makkiyah dan Madanîyah. Pengulangan kisah Musa itu menunjukkan adanya perbedaan spirit universal yang terdapat dalam masing-masing fase. Dalam fase Makkîyah, kisah Musa lebih menekankan pada hubungan umum antara Musa di satu sisi, dan Fir'aun dengan para koleganya di sisi lain. Sementara kisah Musa dalam surat-surat Madanîah menunjukkan hubungan antara Musa dengan Bani Israil, dan hubungannya dengan problematika sosial politik. ${ }^{32}$

Sampai di sini dapat ditegaskan bahwa penggambaran kisah Musa dalam al-Qur'ân tidak dapat dilepaskan dari konteks dakwah yang dilakukan oleh Rasulullah yang mendapat tekanan dan perlawanan dari kaum musyrikin Quraish dan umat Yahudi, baik di Makkah maupun Madinah. Tekanan dan perlawanan yang dihadapi oleh Rasulullah sebanding dengan apa yang dihadapi oleh Musa. Ia dan kaumnya merupakan gambaran masa lalu, sementara Nabi Muhammad dan kaumnya merupakan gambaran masa mutakhir dari situasi yang melingkupi dakwah Islam. Oleh karena itu, ketika Rasulullah sedang menghadapi tekanan dan siksaan yang pedih dari kaumnya maka beliau bersabda yang artinya:

"Semoga Allah merahmati saudaraku Musa. Sungguh ia telah disakiti melebihi ini, tetapi ia bersabar". ${ }^{33}$

Sabda Rasulullah ini sejalan dengan ayat al-Qur'ân yang artinya: Hai orang-orang yang beriman, janganlah kamu menjadi seperti orang-orang yang menyakiti Musa. Maka Allah membersihkannya dari tuduhan-tuduhan yang mereka katakan. Dan dia adalah seorang yang mempunyai kedudukan terhormat di sisi Allah. ${ }^{34}$

Ayat tersebut mengisyaratkan larangan bagi orang-orang mukmin untuk tidak menyakiti Rasulullah sebagaimana orang-orang (Bani Israil) menyakiti Musa. M. Quraish Shihab berpendapat bahwa pesan ayat ini terkait dengan ketidak-taatan kaum musyrikin dan orang-

\footnotetext{
31 Ibid., 422.

32 M. H. Ma'rifat, Kisab-kisah al-Qur'an antara Fakta dan Metafora, terj. Azam Bahtiar (Jakarta: Citra Gria Aksara Hikmah, 2013), 54.

33 Muhammad Sayyid Țanțâwî, al-Qișsah fî al-Qur'ân al-Karîm, Vol. 1 (Kairo: Dâr Nahḍah Miṣr li al-Ṭibâ'ah wa al-Nashr wa al-Tawzî‘, 1996), 317.

${ }^{34}$ Departemen Agama Republik Indonesia, Al-Qur'ân dan Terjemahnya, 680.
} 
orang munafik kepada Nabi Muhammad terkait dengan ejekan mereka terhadap perkawinan beliau dengan Zainab padahal perkawinan itu bertujuan baik, yaitu membatalkan tradisi Jahiliyah yang buruk tentang dampak adopsi. Tuduhan mereka yang sangat menyakitkan hati Rasulullah itu serupa dengan tuduhan yang pernah dilontarkan Bani Israil kepada Musa. ${ }^{35}$

Imâm al-Râzî dalam menjelaskan ayat tersebut di atas juga menambahkan bahwa di antara tuduhan Bani Israil kepada Musa itu adalah mereka mengatakan kalau Musa memiliki aib di tubuhnya (tidak memiliki alat kelamin), dan bahwa Musa pernah melakukan persetubuhan dengan seorang pelacur. ${ }^{36}$

Begitulah Rasulullah mengingatkan kepada pengikutnya tentang kesabaran Musa atas siksaan dan tekanan yang dilakukan oleh Bani Israil, dan bahkan orang-orang mukmin dilarang untuk melakukan perbuatan (dengan menyakiti Rasulullah) seperti yang dilakukan oleh kaum Musa. Di sini, seolah ada persamaan antara tantangan yang dihadapi oleh Rasulullah dengan tantangan yang dihadapi oleh Musa. Oleh karena itu, korelasi cerita Musa dengan dakwah Nabi Muhammad dapat digambarkan sebagaimana berikut:

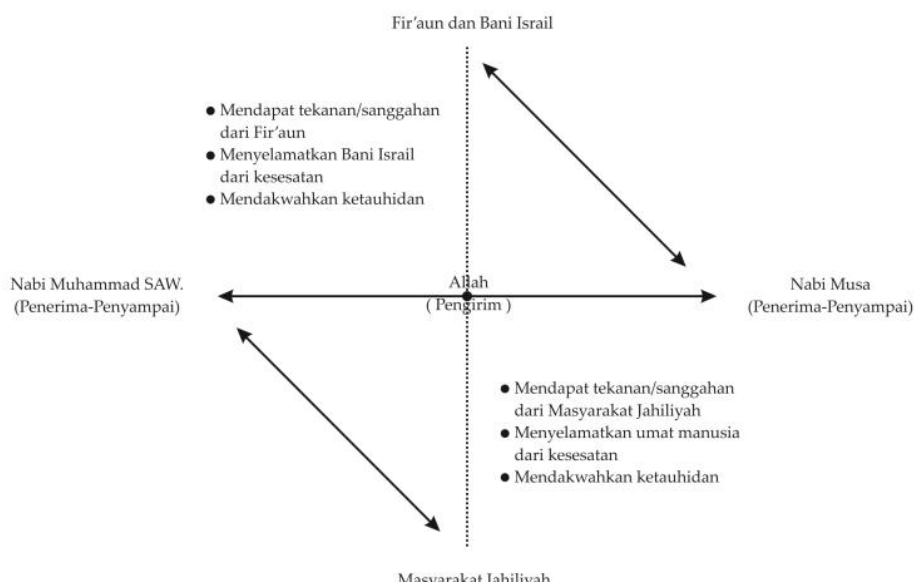

Masyarakat Jahiliyah

Bagan XIII:

Korelasi Cerita Nabi Musa dengan Dakwah Nabi Muhammad

${ }^{35}$ M. Quraish Shihab, Tafsir al-Mishbah: Pesan, Kesan, dan Keserasian al-Qur'an, Vol. 11 (Jakarta: Lentera Hati, 2007), 328.

36 al-Imâm Muḥammad al-Râzî, Tafsîr al-Fakhr al-Rậ̃̂̂, Vol. 25 (Beirut: Dâr al-Fikr, 1981), 234. 
Allah mengirimkan pesan cerita Nabi Musa kepada Nabi Muhammad untuk disampaikan kembali kepada umat manusia. Narasi cerita itu memberikan makna kepada tindakan manusia melalui struktur hubungan interpersonal dan kerangka representasi ruangwaktu. Menerima cerita Musa berarti memahami makna dari pengalaman-pengalaman yang telah dilalui olehnya. Bagi Nabi Muhammad sendiri, sebagai penerima-penyampai pesan, pengalaman yang dialami oleh Musa menjadi pintu masuk untuk memahami diri sendiri khususnya, dan memahami identitas diri umat manusia pada umumnya. Melalui struktur naratif itu, penerima pesan akan dapat memahami dan memaknai episode-episode masa lalu, dan menata aktivitas di masa depan.

Dalam kerangka seperti itulah, cerita Musa hadir sebagai spirit bagi batin penerimanya, yaitu meringankan beban batin Nabi Muhammad dan umat Islam akibat tekanan yang dilakukan oleh para penentang dan musuh-musuhnya; menumbuhkan kepercayaan diri dan menghilangkan kegelisahan atau ketakutan, di samping mengendalikan persepsi dan kesadaran umat manusia akan visi spiritual-eskatologis yang nyata.

Al-Qur'ân sendiri menyatakan "Dan semua kisah dari rasul-rasul Kami ceritakan kepadamu, ialah kisah-kisah yang dengannya Kami teguhkan hatimu; dan dalam surat ini telah datang kepadamu kebenaran serta pengajaran dan peringatan bagi orang-orang yang beriman". ${ }^{37}$ Kata pengajaran (maw'izah) dan peringatan (dḥikrâ) mengisyaratkan sebuah makna yang tidak dapat dipisahkan dari persepsi-kesadaran manusia. Istilah dḥikrâ juga disebut di tempat lain dalam konteks tujuan dari sebuah penceritaan, yaitu surat Tâha ayat $99 .{ }^{38}$

Sampai di sini jelaslah bahwa kehadiran kisah Musa dalam alQur'ân di hadapan Rasulullah memiliki tujuan utama, yaitu meneguhkan hati beliau, meskipun kisah itu disampaikan dan diungkapkan secara berbeda. Al-Baqilânî berpendapat bahwa pengulangan (al-tikrâr) merupakan salah satu segi keindahan al-

\footnotetext{
${ }^{37}$ Q.S. Hûd [11]: 120.

38 "Demikianlah Kami kisahkan kepadamu (Muhammad) sebagian kisah umat yang telah lalu, dan sesungguhnya telah Kami berikan kepadamu dari sisi Kami suatu peringatan".
} 
Qur'ân. Jika sesuatu disebut secara berulang-ulang, maka itu berarti bentuk penegasan atau ada suatu makna yang lebih (ma'nâ ₹ầid). ${ }^{39}$

Ketika menjelaskan tentang pengulangan kisah dalam al-Qur'ân, al-Khaṭ̂b al-Iskâfiy berpendapat bahwa berbagai pengisahan (almạ̣kiyât) dalam al-Qur'ân tidak harus memiliki kesamaan karena pada satu tempat ia hadir dengan menggunakan lafal tertentu dan di tempat yang lain hadir dengan menggunakan lafal lain yang semakna. Lebih dari itu, situasi yang dihadapi oleh para nabi dalam menyampaikan peringatan (al-indhâr) dan kabar gembira (al-tabshîr) kepada umatnya berbeda-beda dari satu waktu ke waktu yang lain; pesan yang disampaikan sama sementara mereka yang menentang dakwah nabi butuh pada jawaban yang beragam sesuai dengan kondisi mereka. ${ }^{40}$

Dengan demikian dapat dikatakan bahwa cerita Musa-dengan pengulangan dan berbagai perbedaan pengungkapannya-di dalam alQur'ân telah menyuguhkan nilai etis-paradigmatis. Ia berbicara untuk suatu kesadaran yang terbuka. Struktur naratifnya lebih memelihara imajinasi dan mengguncang perasaan dari pada mengurung dalam kategori-kategori yang mengikat dan terbatas. Semua itu tidak bisa dilepaskan dari tujuan untuk meneguhkan perjuangan Rasulullah dalam menyampaikan dakwah agama Islam di satu sisi, dan mengubah kesadaran masyarakat melalui nilai etis yang terdapat dalam cerita.

Demikianlah cerita menjadi cara untuk menyampaikan gagasan dan nilai dalam al-Qur'ân sehingga mudah dikenal. Melalui cerita nilai yang hendak disampaikan oleh al-Qur'ân ditampilkan sedemikian rupa lewat tokoh-tokoh dan peristiwa yang di dalamnya audien (penerima pesan) seolah-olah diajak terlibat secara langsung. Penyampaian nilainilai al-Qur'ân melalui cerita tampak lebih dinamis karena lebih cenderung menggunakan bahasa yang konkret dan tanpa ada rasa untuk menggurui karena di dalamnya terjadi dialog secara tidak langsung antara para pemeran cerita dengan penerima pesan: di dalamnya terdapat dialog pengalaman secara langsung antara tokoh cerita dengan audien. Nilai-nilai yang disampaikan lewat cerita jauh dari penghakiman (judgment) yang seringkali menimbulkan rasa tidak simpati pada pihak audien.

39 Abî Bakr Muhammad b. al-Ṭayyib al-Bâqilânî, I'jâz al-Qur'ân (Mesir: Dâr alMa'ârif, t.th.), 160.

40 Al-Khatib al-Iskâfî, Durrat al-Tanzîl wa Ghurrat al-Ta'wîl, ed. Muhammad Muștafâ Âyidayn, Vol. 2 (Makkah al-Mukarramah: Jâmi'at Umm al-Qurâ, 2001), 598-599. 


\section{Penutup}

Struktur naratif kisah Musa dibangun oleh peristiwa-peristiwa yang terhubung secara kausal dan terkait secara fungsional sehingga terbangun alur yang logis dan bermakna. Struktur naratif ini memiliki fungsi etis, yaitu membawa visi spiritual-eskatologis kepada umat manusia, yaitu memberikan makna kepada tindakan manusia, sehingga penerima pesan dapat memahami dan memaknai episodeepisode masa lalu, dan menata aktivitas kehidupan di masa mendatang. Bangunan yang menghubungkan antara aktan menampakkan suatu bangunan yang tidak berubah, yaitu Pencerita-PenciptaPengirim (Allah) sebagai penyampai pesan, penerima pertama (Nabi Muhammad) sebagai hamba yang menerima pesan dari Allah untuk disampaikan kepada umat manusia, dan penerima kedua (umat manusia).

Narasi kisah Musa memperlihatkan dimensi kemukjizatan naratif (al-ijajaz al-sardiy) dari al-Qur'ân. Kemukjizatan naratif ini dicirikan oleh dua hal. Pertama, struktur bahasa dan komunikan dari kisah Musa di dalam al-Qur'ân bersifat benar karena sangat berguna bagi kesadaran umat manusia dan mampu menembus kesadaran mereka secara efektif. Kedua, struktur bahasa dan komunikan dari kisah Musa di dalam al-Qur'ân bersifat efektif karena elemen-elemen dan bagian cerita dibangun secara konsisten dan koheren. Konsekuensinya, kebenaran narasi kisah dalam al-Qur'ân diukur oleh tingkat konsistensi dan koherensi internal dari elemen-elemen organisasional dan struktural yang membangun sebuah cerita. Cerita memiliki koherensi ketika semua bagian atau potongan cerita hadir secara fungsional dan tidak meninggalkan detail-detail yang tidak penting. Konsep kebenaran dalam paradigma naratif bukan merupakan rasionalitas yang didasarkan pada tingkat kesesuaian bagian cerita dengan realitas tetapi pada kesadaran orang tentang bagaimana sebuah cerita itu konsisten secara internal dan benar sebagaimana pengalaman hidup yang dijalani.

\section{Daftar Rujukan}

'Abduh, Muhammad 'Abd Allâh. Usus Binâ' al-Qișsah li al-Qur'ân. Kairo: Jâmi'at al-Azhar, 1996.

Arkoun, Mohammed. Berbagai Pembacaan Quran, terj. Machasin. Jakarta: INIS, 1997.

Arkoun, Mohammed. Pemikiran Arab, terj. Yudian Wahyudi. Yogyakarta: Pustaka Pelajar, 1996. 
Bâqilânî (al), Abî Bakr Muḥammad b. al-Ṭayyib. I'jâz al-Qur'ân. Mesir: Dâr al-Ma'ârif, t.th.

Dabûr, Muḥammad 'Abd Allâh 'Abduh. "Usus Binâ' al-Qiș̣ah min alQur'ân al-Karîm: Dirâsah Adabîyah wa Naqdîyah”. Disertasi-Jâmi'at al-Azhar, Kairo, 1996.

Forster, E. M. Aspects of The Novel. London: Harcourt Inc., 1985.

'Imârah, Maḥmûd Muḥammad Muhammad. Fiqh al-Da'wah min Qiṣsah Musa 'alayh al-Salâm. Kairo: Maktabat al-Imân, 1997.

Iskâfî (al), Al-Khatib. Durrat al-Tan₹îl wa Ghurrat al-Ta'wîl, ed. Muhammad Muștafâ Âyidayn, Vol. 2. Makkah al-Mukarramah: Jâmi'at Umm al-Qurâ, 2001.

Jâbirî (al), Muḥammad 'Âbid. Madkhal ilâ al-Qur'ân al-Karîm, Vol. 1.

Beirut: Markaz Dirâsât al-Waḥdah al-'Arabîyah, 2006.

Khalaf Allâh, Muhammad Aḥmad. al-Fann al-Qașașî fî al-Qur'ân alKarim. Kairo: Maktabat al-Nahḍah al-Mișrîyah, 1951.

Khatîb (al), 'Abd al-Karîm. al-Qasas al-Qur'ânî fî Mantûqih wa Mafbûmih. Beirut: Dâr al-Ma'rifah, 1975.

Ma'rifat, M. H. Kisah-kisah al-Qur'an antara Fakta dan Metafora, terj. Azam Bahtiar. Jakarta: Citra Gria Aksara Hikmah, 2013.

Mazârî, Shârif. Mustawayât al-Sard al-I'jâzî̀ fì al-Qișah al-Qur'ânîyah.

Damaskus: Manshûrât Ittihâd al-Kuttâb al-'Arab, 2000.

Minderop, Albertine. Metode Karakterisasi Telaah Fiksi. Jakarta: Yayasan Pustaka Obor Indonesia, 2011.

Nurgiyantoro, Burhan. Teori Pengkajian Fiksi. Yogyakarta: Gadjah Mada University Press, 2010.

Quṭb, Sayyid. al-Tașîr al-Fannî fì al-Qur'ân. Kairo: Dâr al-Ma'ârif, t.th.

Râzî (al), al-Imâm Muhammad, Tafsîr al-Fakhr al-Râzî̀, Vol. 25. Beirut: Dâr al-Fikr, 1981.

Sa'd, Aḥmad Abû. Fann al-Qișsah. Beirut: Manshûrât Dâr al-Sharq alJadîd, 1959.

Shihab, M. Quraish. Tafsir al-Mishbah: Pesan, Kesan, dan Keserasian alQur'an, Vol. 11. Jakarta: Lentera Hati, 2007.

Spaulding, Amy E. The Art of Storytelling. United Kingdom: The Scarecrow Press, 2011.

Stanton, Robert. Teori Fiksi, terj. Sugihastuti dan Rossi Abi al-Irsyad. Yogyakarta: Pustaka Pelajar, 2012. 
Ṭanțâwi, Muhammad Sayyid. al-Qișsah fî al-Qur'ân al-Karîm, Vol. 1. Kairo: Dâr Nahḍah Miṣr li al-Ṭibâ'ah wa al-Nashr wa al-Tawzî‘, 1996.

Takwin, Bagus. Psikologi Naratif: Membaca Manusia sebagai Kisah (Yogyakarta: Jalasutra, 2007), 17-18.

Tûnjî (al), Muhammad. al-Mújam al-Mufașsal fì al-Adab, Vol. 2. Beirut: Dâr al-Kutub al-'Ilmîyah, 1993. 